\title{
Germany will ease requirements of gene technology laws in bow to researchers
}

Munich. Germany's federal government has agreed in principle to relax the way its gene technology laws are administered after a long campaign by scientists to reduce the number of forms and lengthy authorization procedures.

But the changes come too late for a laboratory in Marburg, which was closed down last week by the regional Ministry of the Environment. Researchers, whose equipment and notebooks have been seized even though the research had previously been designated as without risk, believe the action was an attempt to forestall liberalization of the laws.

Molecular biology in Germany has been undermined by a powerful anti-genetic-engineering lobby that has stifled research and left the country trailing the rest of Europe. Laws introduced in July 1990 continued the trend by requiring elaborate safety procedures and time-consuming recordkeeping - irrespective of the level of risk involved in experiments (see Nature 359, 93; 1992). But a concerted campaign by academic and industrial scientists has now borne fruit.

The government has agreed that procedures for monitoring experiments will be relaxed. Gebhard Ziller, state secretary at the ministry of research and technology, last Friday told a meeting on gene technology organized by the European Patent Office in Munich that the government would be "taking steps to remedy the morass of bureaucratic procedures" by amending the Genetic Engineering Act and simplifying the administration. The changes would not lower safety standards, he assured critics. Experiments that by definition pose no risk will no longer need to be reported to the authorities once a general authorization has been received. The government is also expected to remove an automatic three-month delay in granting permission for experiments designated as 'very low risk'. The law is on the second of three readings in parliament, and the

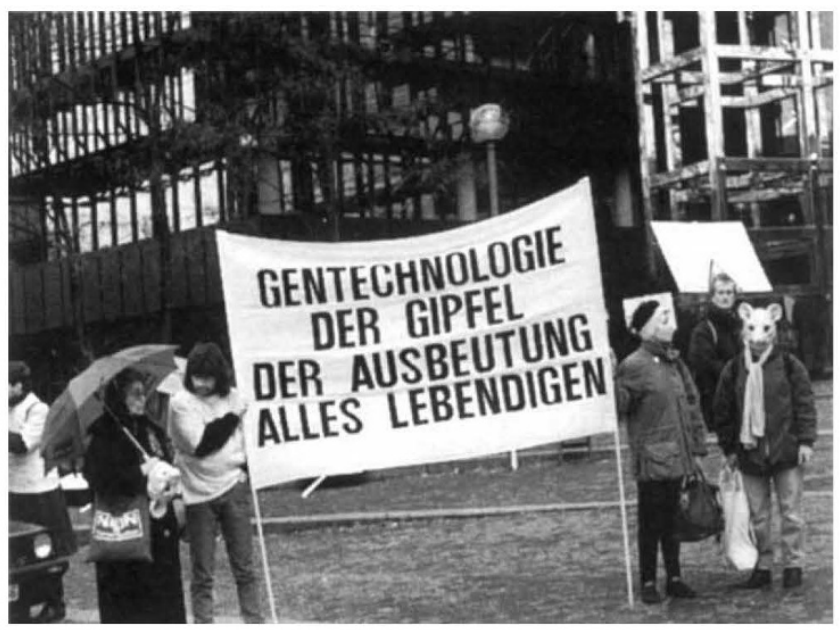

Protesters outside last week's meeting in Munich at the European Patent Office display signs reading, “Gene technology - the ultimate exploitation of all living things".

compliance with the gene laws found that a project run by Klaus Hazemann, head of haematology and oncology at a local hospital, had been moved to an identical laboratory in another part of the building.

Two weeks later, the lucal government decided to take action. Last Thursday, police seized refrigerators and freezers to check the plasmids being used - an almost impossible task estimated to involve the sequencing of up to half a billion kilobase pairs. They also took notebooks that did not conform to the strict requirements of the law. A spokesperson for the ministry said that the law had been broken and that researchers must start the complex application procedure from scratch.

Response has verged on the hysterical. Local papers have reported that the laboratory was releasing 'carcinogenic bacteria' into the environment. In fact, Hazemann is looking at IGF binding proteins that have a negative effect on cellular proliferation and is investigating the mechanisms controlling the genes for these proteins. The work, which has implications for some types of lung cancer, had previously been defined as belonging to the

Ministry of Public Health is confident that it will be in place by January 1994 .

In the meantime, the Department of the Environment in Hessen, one of Germany's 16 federal states and led by the Green party, has unexpectedly closed a research laboratory at the Institute of Molecular Biology and Tumour Research of the University of Marburg. Health and safety officers conducting a routine inspection to check

\section{Protesters picket patent office}

Munich. The European Patent Office has become the target of anti-genetic-engineering activists after its recent granting of Europe's first animal patent - the Harvard oncomouse. Although last Friday's symposium (see above), attended by both scientists and representatives of lobbying organizations, was intended to ease public concern over genetic engineering, the local group Kein Patent auf Leben (No Patents on Life) claimed that its opinion has continued to be ignored.

As a consequence, the group assembled 150 demonstrators from five European countries to picket the meeting. A spokesman, Christof Then, complained that there was no opportunity for objectors to lobby participants directly and promised that his group would continue protesting against the granting of patents on life forms both in Germany and at the European Communities headquarters in Brussels.

"We are against biotechnology in general", he says. "We are against relaxing of the gene laws; with such a young technology it's too dangerous."

A.A. lowest of the four categories of risk level outlined in the gene law, that is, posing no risk for human health or the environment, although the laboratory was originally registered for second level - very low-risk - experiments.

Hans-Dieter Klenk, a member of the university safety commission with responsibility for the institute's laboratories, says that the research group erred in not reporting the change in location, but he disputes claims that the new room is unsafe. Everything was in order during his own inspection, he said.

Klenk says that the proposed changes in the gene laws are extremely important for Hessen, where an anti-gene technology government has hindered research by enforcing the letter of the law. It is not uncommon for scientists to wait a year for permission to conduct a simple experiment.

Researchers throughout Germany welcome the changes. Ernst Winnacker, head of the Biochemistry Institute in Munich, says 80 per cent of all experiments using gene technology are designated 'no risk', and a further 17 per cent are 'very low risk'. "But most important", says Winnacker, "it's a signal that [German science] laws can indeed be adapted to technological changes".

Alison Abbott 